\title{
照明學會㗎䜅
}

第 22 卷

昭 和 13 年 3 月

第 3 號

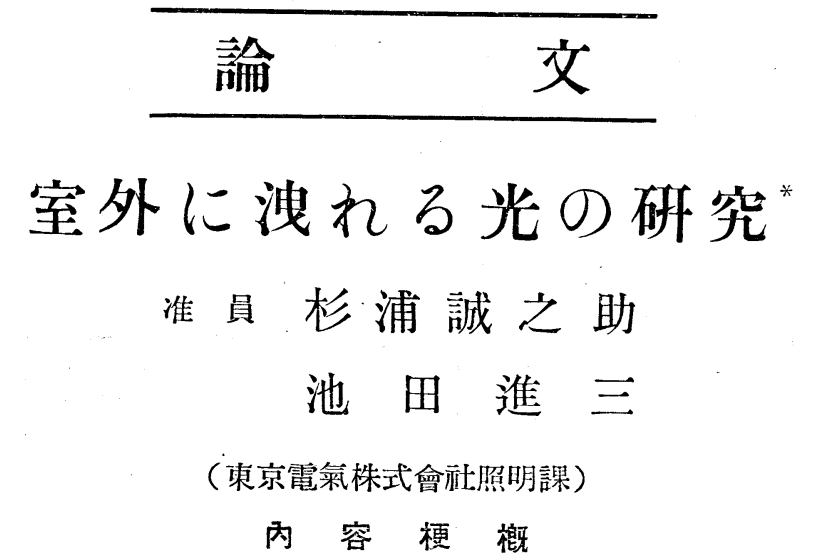

室內の電燈の光は漳子面, 屝面等室の開放部を通して外部に洩れるこの量を洋室及和室に就き實測した もので, 照明方法を色々に變へ，本常通り㸃登せる場合及直射光を遮つた場合つ二通りを行つた。倘各照 明方法に就き同一休面照度に對する漏光の多少を比較した・之等は何れむ燈火管制に關係岁る閣題である。

目次

1. 實驗の目的

2. 譬 驗 方 法

3. 照明方法及照明器具

4. 實 驗 結 果 $\left\{\begin{array}{l}(イ) \text { 床面照度 } \\ (\text { 口 }) \text { 開放部の照度 } \\ (ハ) \text { 暈光となる光束 } \\ (=\text { 減光材料の透過率 }\end{array}\right.$

1. 實 驗 の目的

目的の (1) は開放部に於ける照度の概數を求めるてと。その (2)は室內を本常通り照明した 場合と, 減光且つ遮光して反射光のみ出る場合との照度比即ち前者の漏渑光束を後者のそれに 等しからしめる爲めの減光材料の透過率を求めることにある.

\section{2. 實驗室及實驗方法}

實驗に供せられた室はマッダ照明學校內の日本間及洋間各 1 室で，第1，2圖にその狀態を示 した・日本間は 8 疊で廊下に面する障子 4 枚及上部闌間（第 1 圖 B，C) を取外して之を開放部

* Measurement of The Light Leaking from the Interior. By. S. Sugiura, Associate, and S, Ikeda 
之見做し，洋間は $4.0 \times 5.8 \mathrm{~m}^{2}$ (約 7 坷) で第 2 圖 (B) のA面に $2.4 \times 2.1 \mathrm{~m}^{2}$ の開放部 がある．何れもその鉛直面照度をマクベス照度計で测つた（透副試驗板使用）

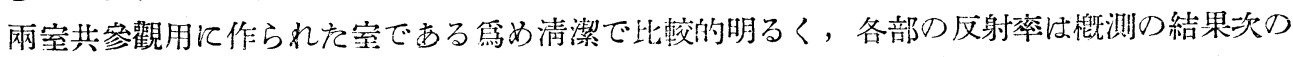
如くである。

\begin{tabular}{|c|c|c|}
\hline \multirow{2}{*}{ 和 } & 堨所 & 反射率 \\
\hline & 舋 & 0.29 \\
\hline & 襖 & 0.58 \\
\hline$P$ & 障 子 & 0.56 \\
\hline
\end{tabular}

\begin{tabular}{|c|c|c|c|}
\hline \multirow[b]{2}{*}{ 洋 } & 場 & 所 & 反射翠 \\
\hline & 白掌 & & 0.61 \\
\hline & & \}白 & 0.80 \\
\hline 室 & 淡黃色壁紙 & & 0.33 \\
\hline 理 & 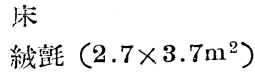 & & $\begin{array}{l}0.11 \\
0.09\end{array}$ \\
\hline
\end{tabular}

(A)
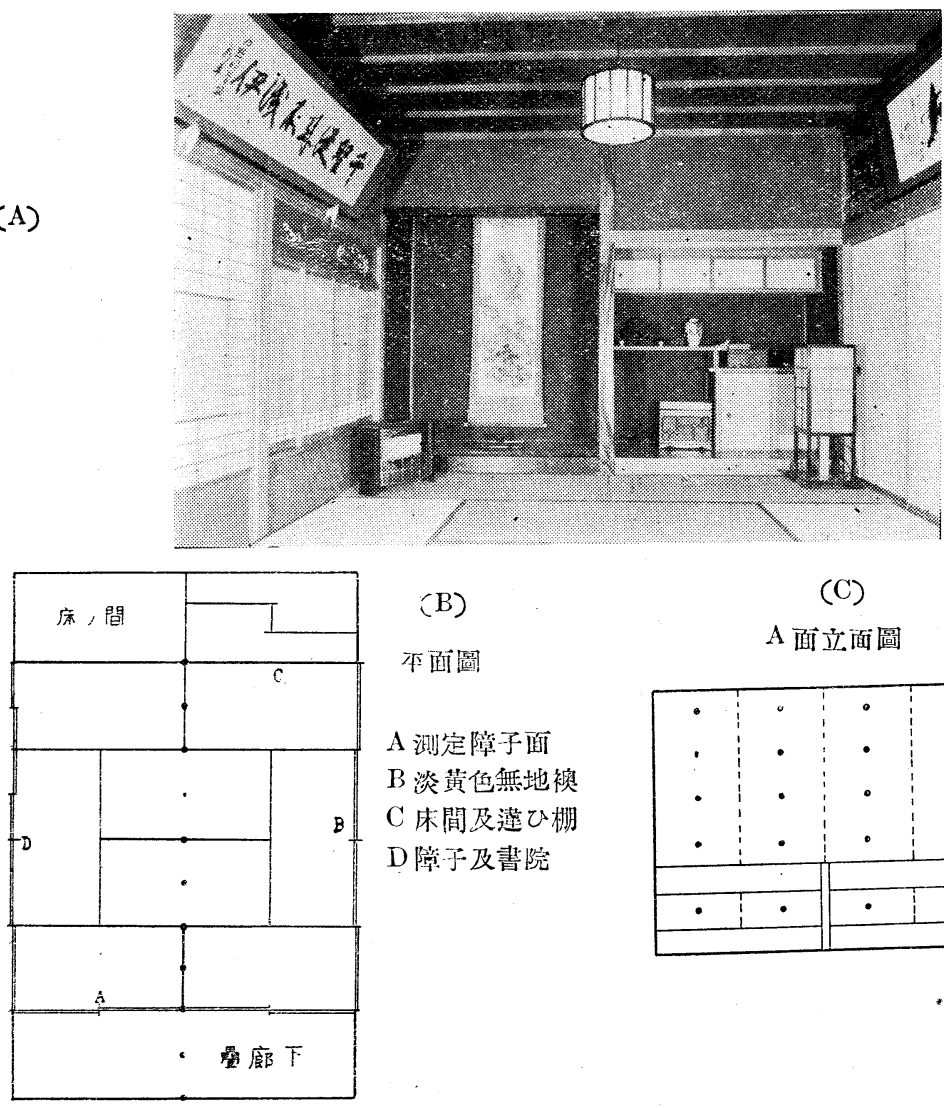

(B)

(C)

本面圖

$A$ 测定障子面

$B$ 淡黄你無地襖

$\mathrm{C}$ 床間及遱ひ棚

D㜔子及書院

A 面立面圖

第 1 圖

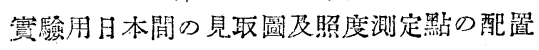

\section{3. 照明方法及照明器具}

（イ）減光遮光の場合 
(A)

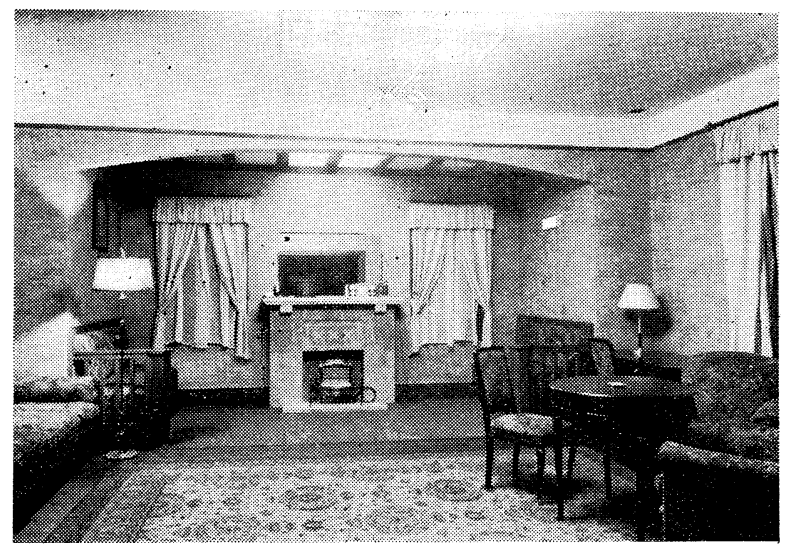

(B) 平面圖
$\mathrm{A}$ 出入口 (開放部) $\mathrm{B}$ 蜜
C 白 壁 (白幕を垂下) $\mathrm{D}$ 淡黄色壁・测定點

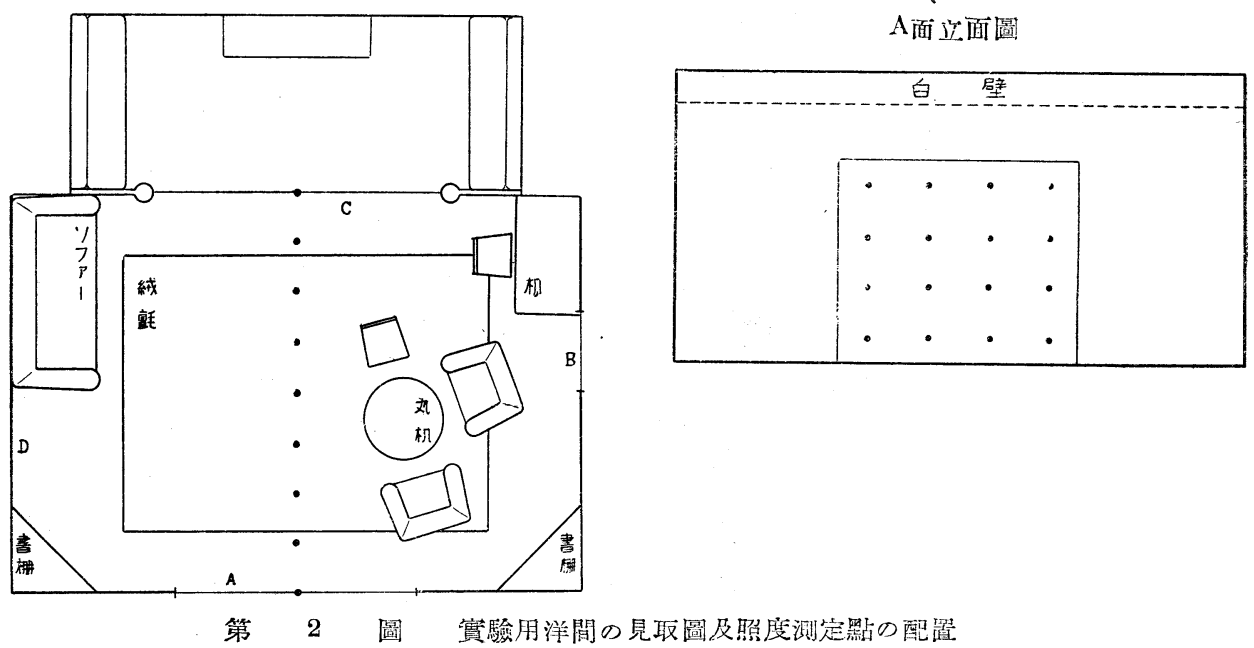

開放部に對して直射光を遮る方法には種々あるが，此處では最も實際的で且つ效率の高い方 法として圖示の 9 種を採用した。

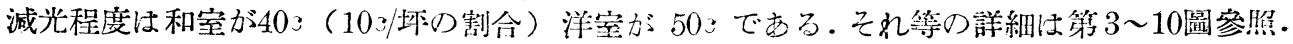
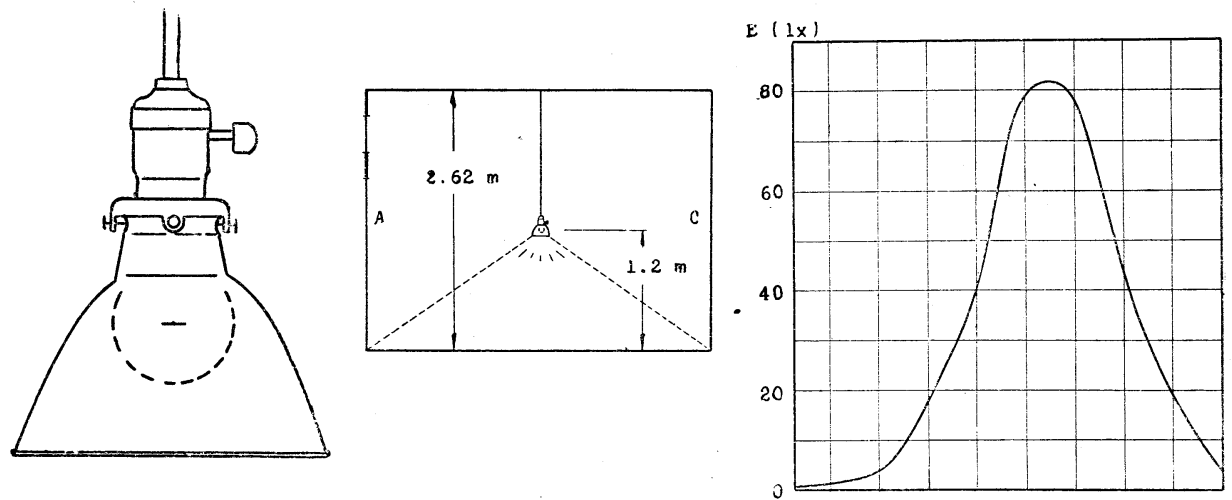

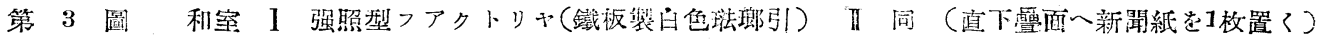



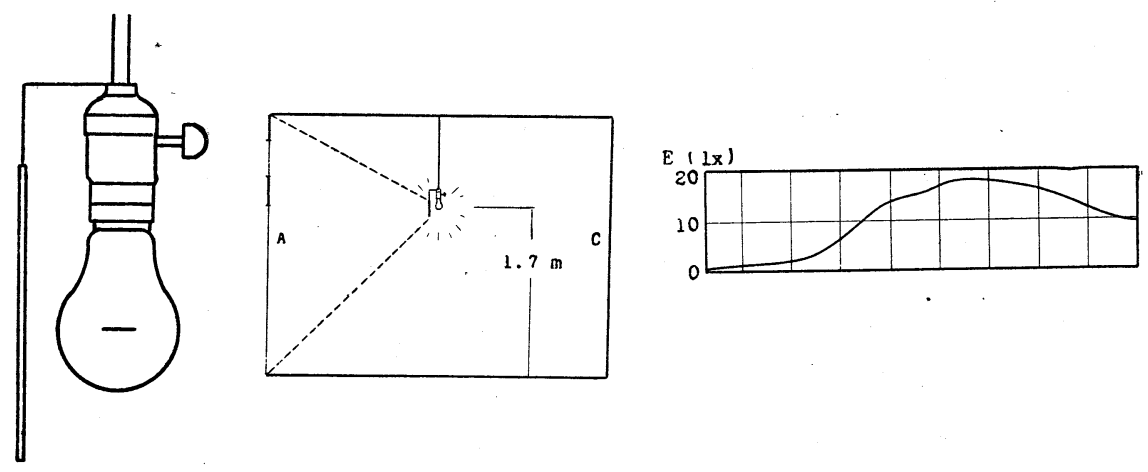

第 4 圖 和室 III 裸電球と紙製遮光板(內面昌色ケント紙 外面黑色ラシャ紙)
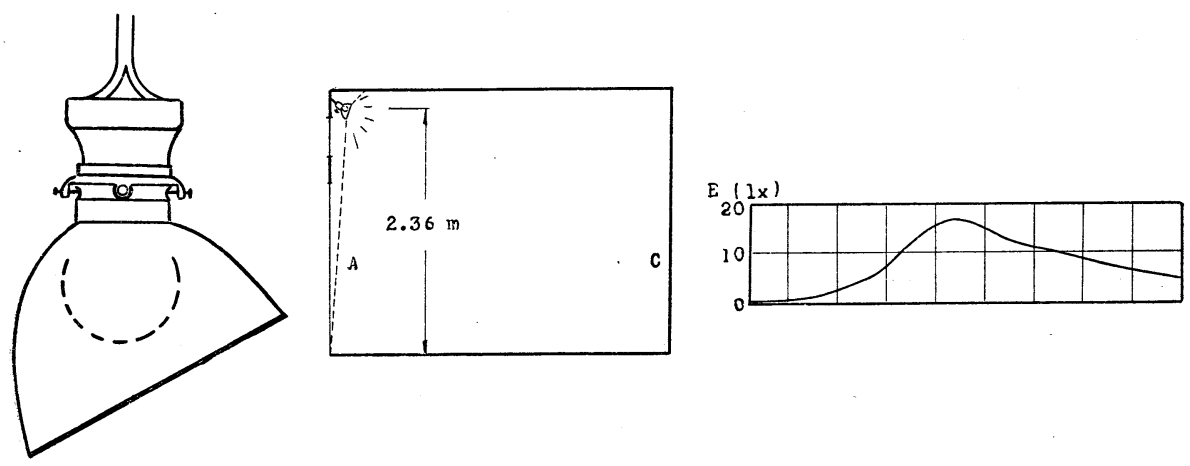

第 5 圖 和空 $1 V$ 解照型フアクトリャ(鐵板製白色珪瑯引)
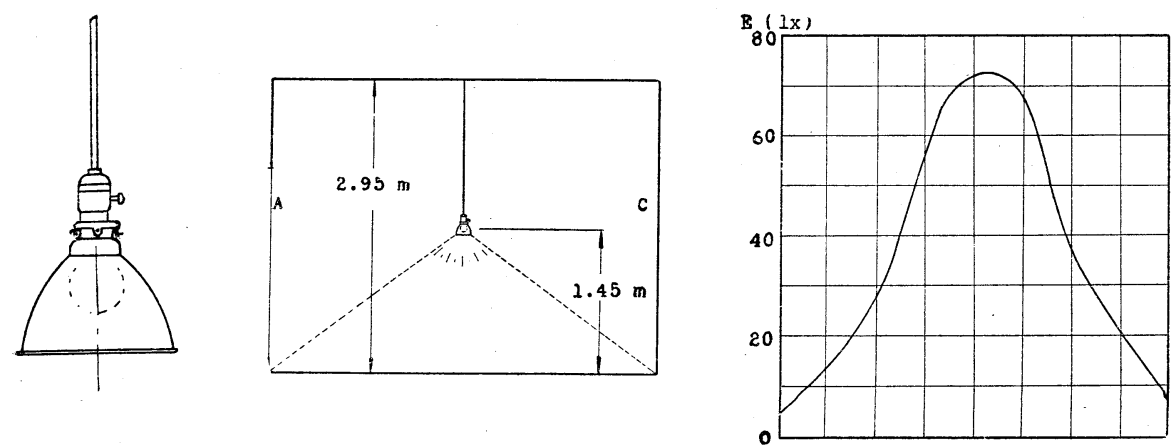

第 6 圖 洋室 I 强照型フアクトりヤ(鐵板製白色䁃郷引) 

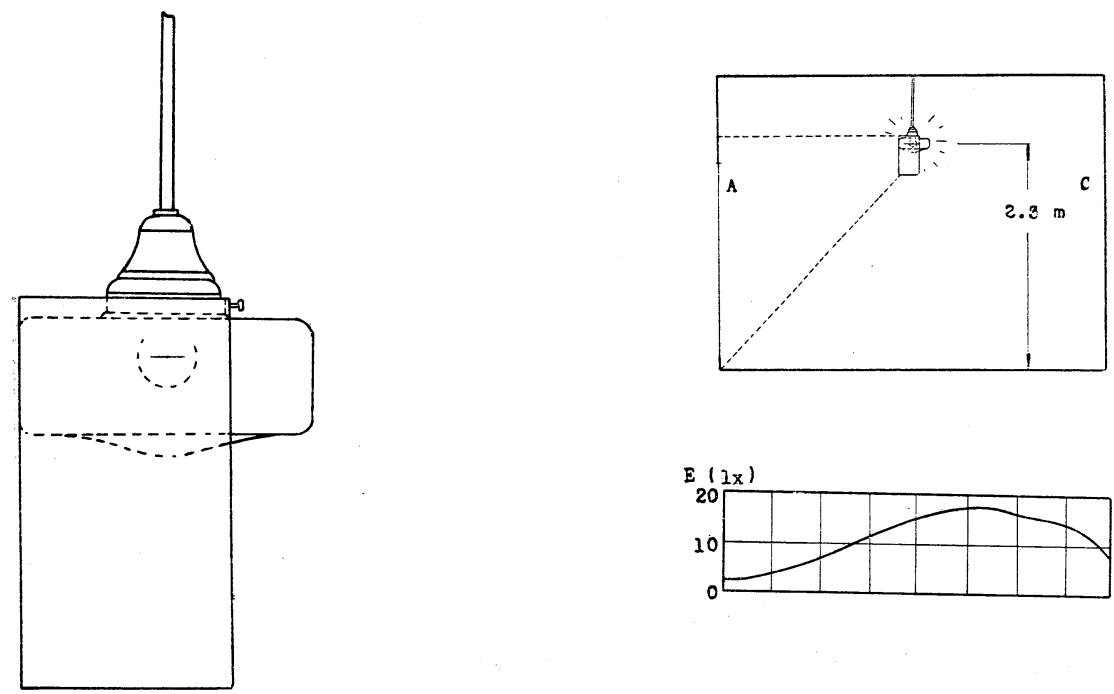

第 7 圖 洋空 II 外球と紙製遮光坂(牛圓形)(內面白色ケント紙 外面黑色ラシャ紙)
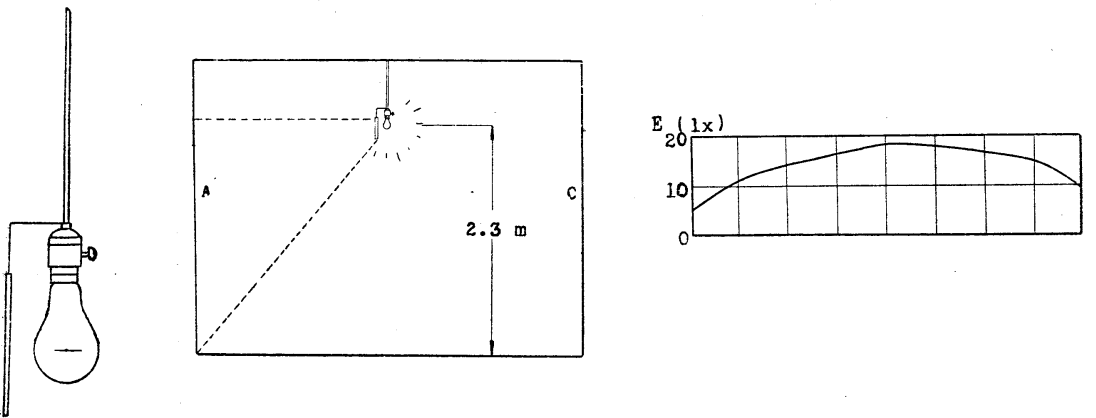

第 8 圖 洋室 血 裸電球と紙製遮光板(內面白色ケント紙 外面黑色ラシャ紙)
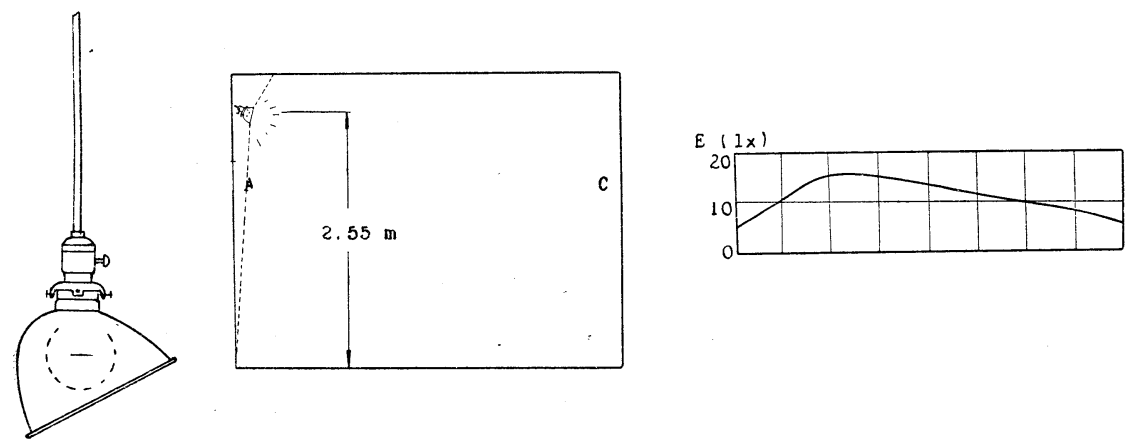

第 9 圖 洋空 IV 解照型フアクトリヤ(鐵板製白色愫郎引) 

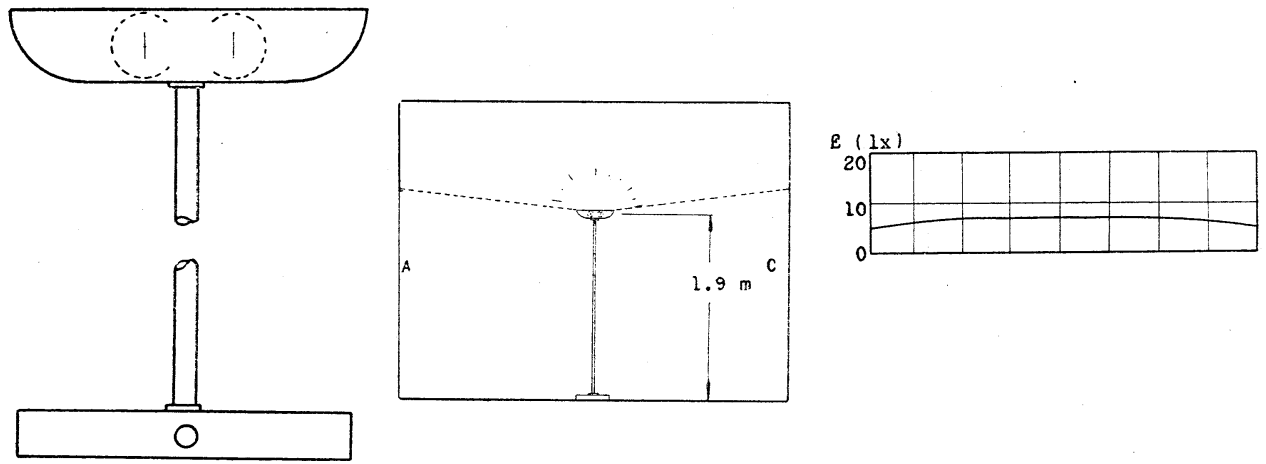

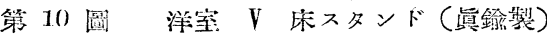

（口）平常通り點燈の場合

開故部に於ける照度は光源が其處に近い程當然大となるが，此處では特殊な例一三を除く以 外光源は總べて室の中央にある場合を考へた。

電球の大きさは和室が $80 \mathrm{~W}$ ，洋室が $150 \mathrm{~W}$ で，何れも大體一般に推獎される $20 \mathrm{~W} /$ 坼の割 合であるから先づ相當明るい方である．但し貫情に即して洋室の半間接照明は $200 \mathrm{~W}$ ，閒接照

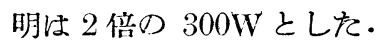

和室の器具には最る普通に用ひられる $\mathrm{P}-1$ 笠, 椀型笠及裸電球の 3 種を, 洋室には裸電 球，外球 3 種（直接，牛直接，牛間接照明）及床スタンド（間接照明）を選んだ。詳細は第 - $11 \sim 18$ 滈參熙.
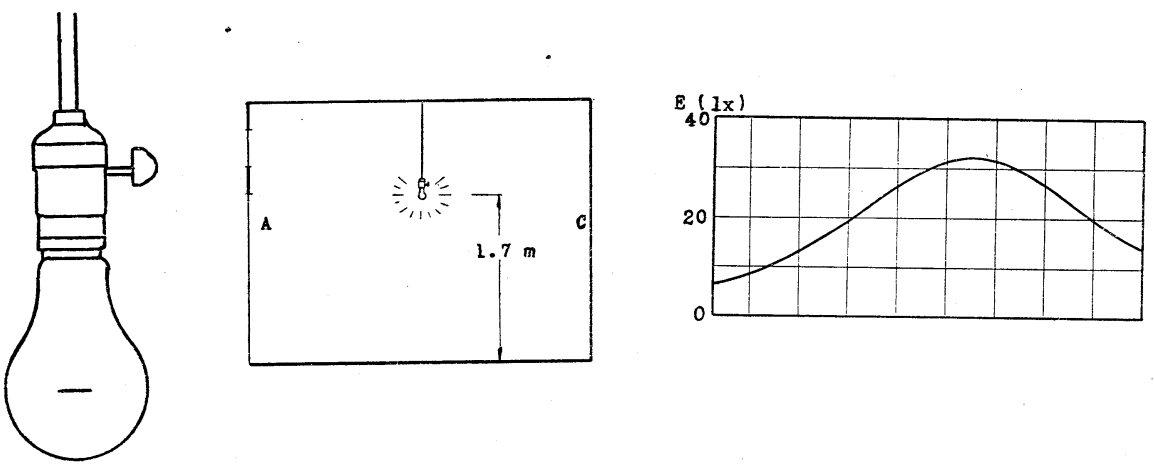

第 11 圖利室 1 裸電球
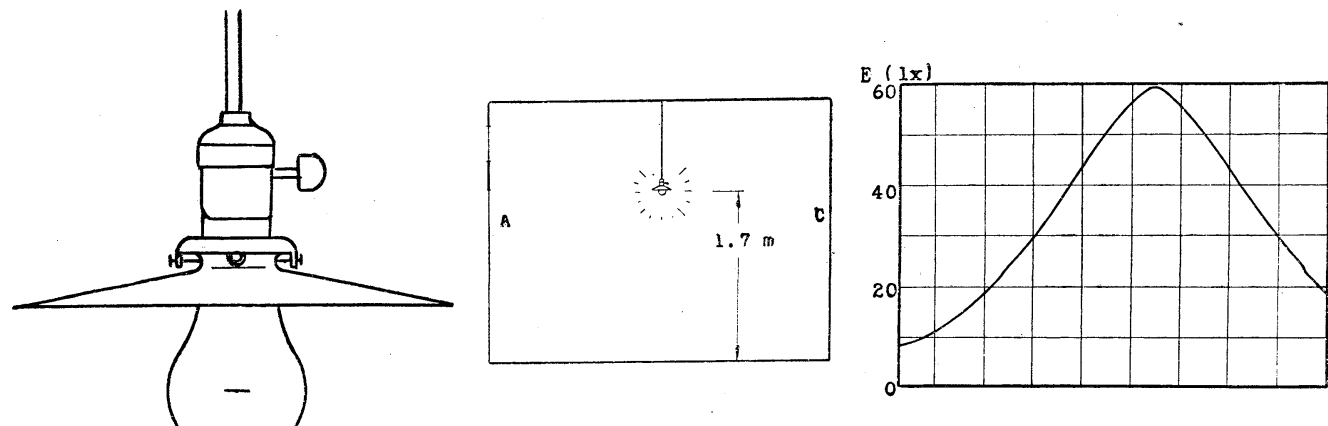

第 12 圖 和宾 $2 \quad \mathrm{P}-1$ 笠 (乳色管子製) 

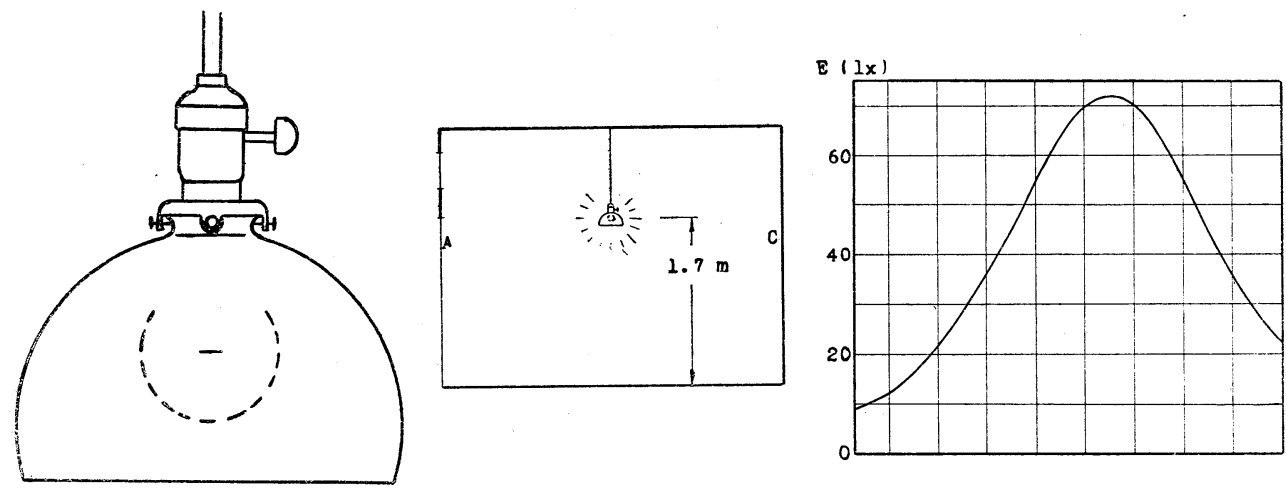

第 13 圖 利室 3 椀型笠 (乳绝确子製)
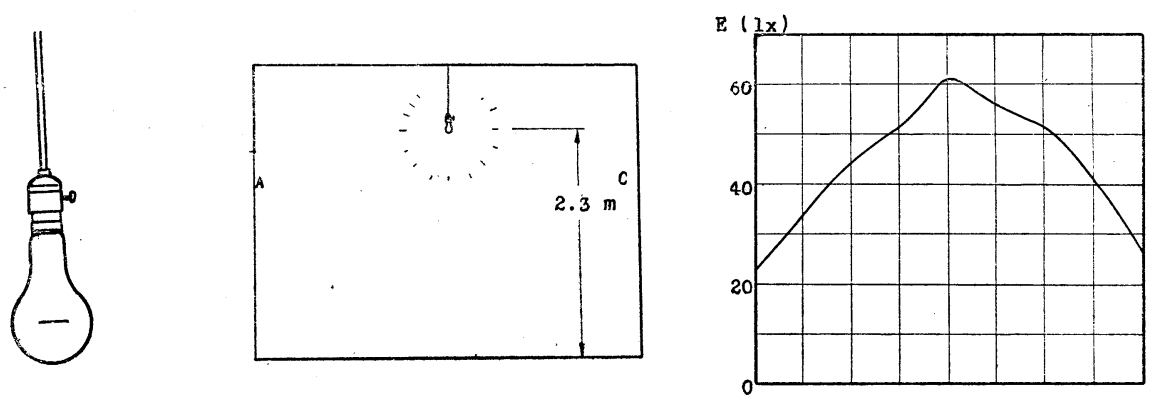

第 14 圖洋宝 1 裸霄球
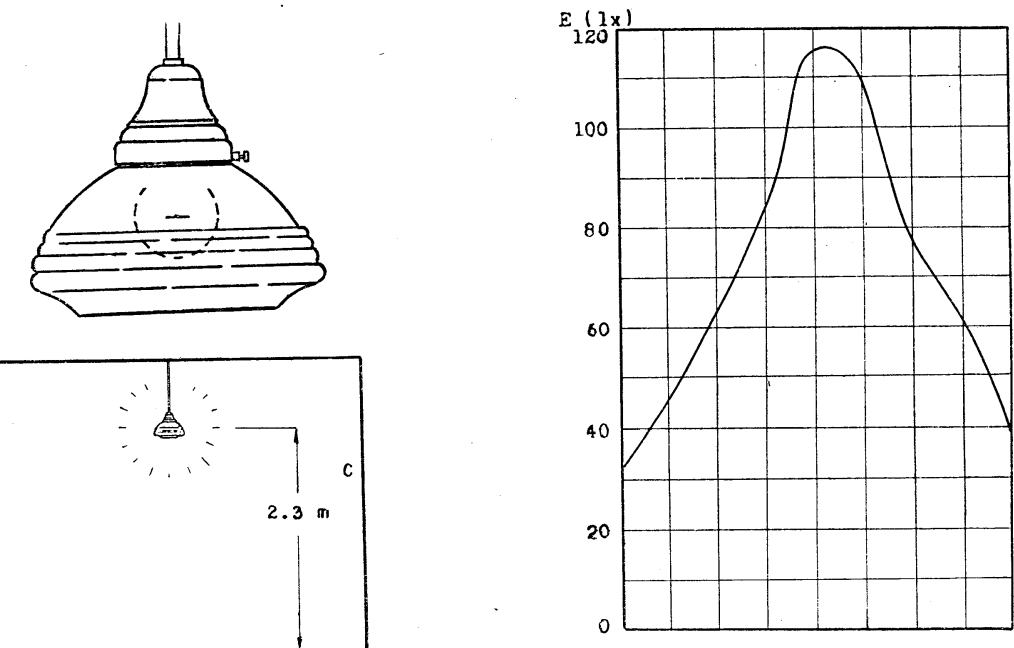

第 15 圖洋室 2 トロデャりヤ(型（パール确子） 

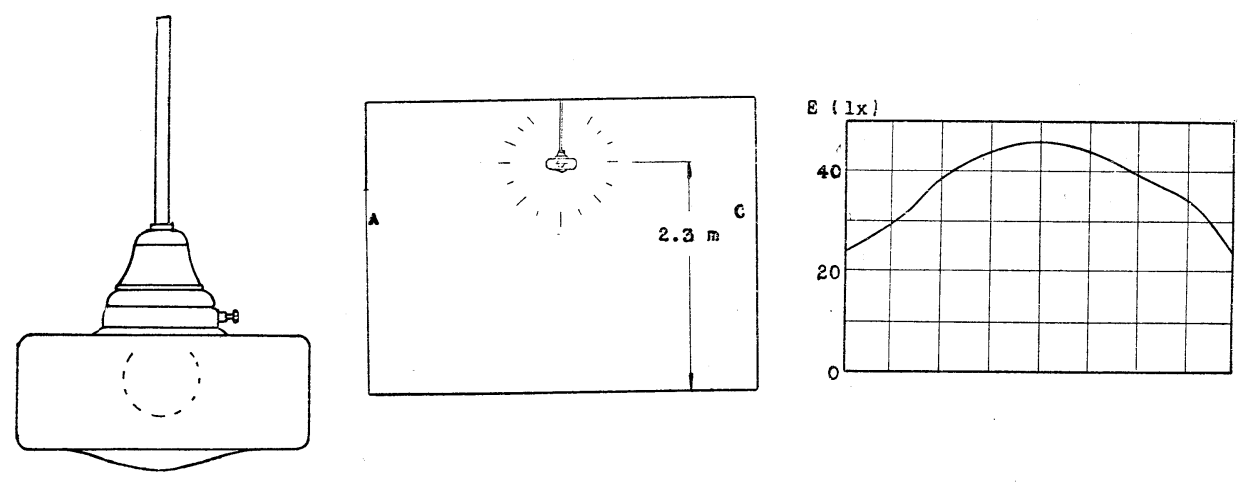

第 16 圖 洋室 3 トロデヤリヤE型（パール衙子）
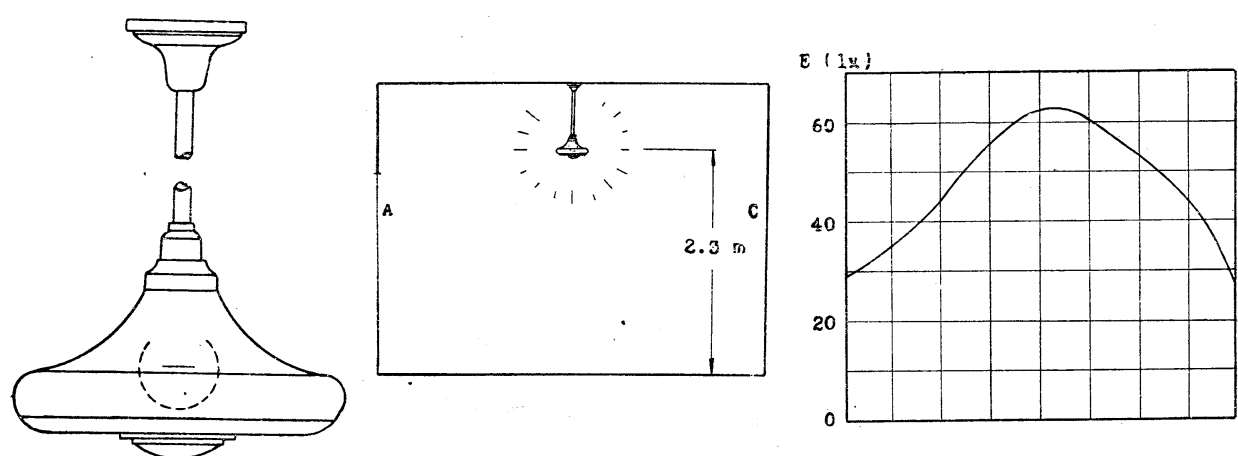

第 17 圖 洋室 4 ケルドン(上牛部內面㧵确子 下牛部乳色硝子)
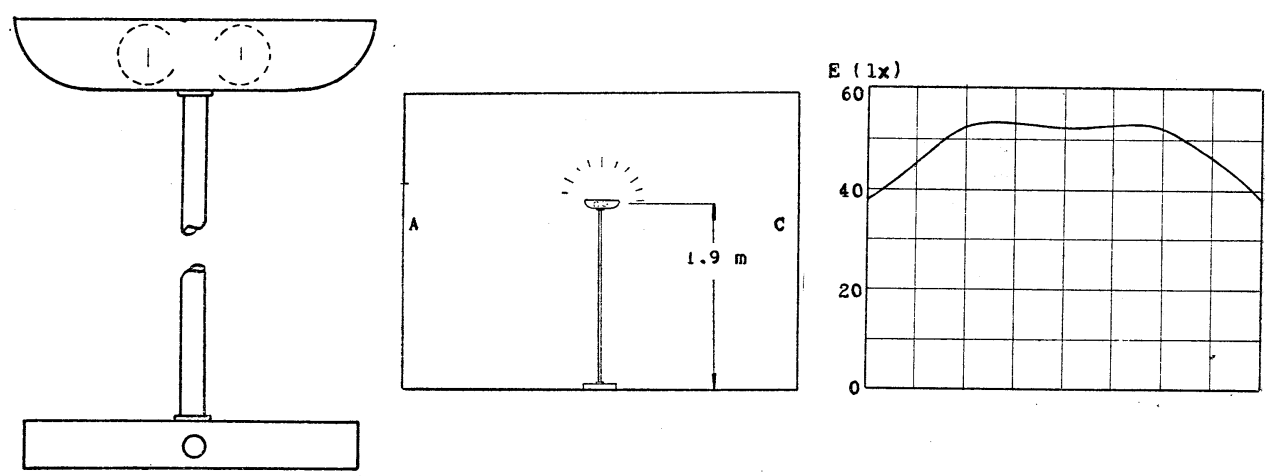

第 18 圖洋室 5 床スタンド(廙鍮製) 


\section{4. 實 驗 結 果}

\section{（イ）床面の照度}

上に述へた17種の照明方法に就き夫ね床面及疊面の照度を測定せるに第 1,2 表の值を得た。 佾照度曲線壮第 $3 \sim 18$ 圆參照.

第 1 表 (和 空)

\begin{tabular}{|c|c|c|c|c|c|c|c|}
\hline \multirow{2}{*}{ 減光遮光 } & \multicolumn{3}{|c|}{$E_{f}(\mathrm{~lx})$} & \multirow{2}{*}{ 平常通り } & \multicolumn{3}{|c|}{$E_{f}(\mathrm{~lx})$} \\
\hline & 本 均 & 最 大 & 最 小 & & 平 均 & 最 大 & 最 小 \\
\hline I & 11.2 & 81.9 & 3.87 & 1 & 24.0 & 32.1 & 13.5 \\
\hline II & 41.4 & 81.9 & 4.08 & 2 & 39.6 & 59.3 & 18.7 \\
\hline III & 12.0 & 18.0 & 1.77 & 3 & 48.6 & 71.9 & 22.2 \\
\hline IV & 9.22 & 16.8 & 2.82 & & & & \\
\hline 平 均 & 26.0 & - & -- & 平 均 & 37.4 & - & 一 \\
\hline
\end{tabular}

第 2 表 (洋 空)

\begin{tabular}{|c|c|c|c|c|c|c|c|}
\hline \multirow{2}{*}{ 減光 遮 光 } & \multicolumn{3}{|c|}{$E_{f}(\mathrm{~lx})$} & \multirow{2}{*}{ 本常通 リ } & \multicolumn{3}{|c|}{$E_{f}(\mathrm{~lx})$} \\
\hline & 平 均 & 最大 & 最 小 & & 平 均 & 最 大 & 最 小 \\
\hline 1 & 34.9 & 71.5 & 5.78 & 1 & 43.2 & 61.4 & 23.0 \\
\hline II & 10.6 & 17.5 & 2.71 & 2 & 69.4 & 115.0 & 32.7 \\
\hline III & 13.8 & 18.3 & 5.25 & 3 & 32.7 & 45.7 & 23.4 \\
\hline IV & 10.6 & 15.7 & 5.24 & 4 & 46.2 & 64.1 & 26.7 \\
\hline $\mathrm{V}$ & 6.5 & 7.23 & 5.15 & 5 & 47.9 & 53.2 & 38.0 \\
\hline 本 均 & 15.8 & - & -- & 本 均 & 47.9 & - & - \\
\hline
\end{tabular}

上表中減光遮光した場合の平均照度を見ると和室 1 , 洋室 $1 の$ 金蜀反射笠を用ひた方法注他 の方法に依る值の約3倍近くを示し，本常通り照明した時つ值と比䎧してたいした孫色が無い。 ての方法が特に工場等の高い照度を要求する場所に推獎し得る所以である.

同じ方法に依り光源直下に新聞紙 1 枚を擴げた場合を試みたが（和室 II）疊面の照度に對し ては殆どその影響が認わられない。

其他の方法に依るものは概ね $10 \mathrm{~lx}$ 內外で, 光源直下の最大值ですら $20 \mathrm{x}$ を超えるるの無 く, 洋室 Vの間接照明が最も低い。

然し乍ら均齊度（最小照度/最大照度）に於ては略照度高いもの程惡く，金屬反射笠の約 
0.05 (和室)，0.08 (洋室) 几對して間接照明（洋室り）怆 0.7 である.洋室は室內周圍の反射

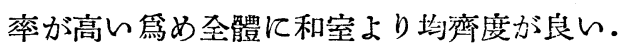

照明面積が狹くとも高照度を要求する場合, 或は照度低くとも廣い照明面積を要求する場合 等，作業の種類に應じて何れの方法を探るべきがは上に述べた條件から豫想出來る。

金昀文射笠を除く他の方法に位る平均照度は，全體を通じて平常通り照明した場合の大體 3 分の 1 程度でする。

平常通り照明した場合の本均照度は約 $25 \sim 701 \mathrm{x}$ で，牛外球（洋室 2 ）の場合最も明るく 69 $\mathrm{lx}$ ，その最大值は $115 \mathrm{~lx}$ 亿達する。裸電球は和洋室共最多曋い。

(口) 開放部の照度

符 1,2 圖 (C) に示す開放部の鉛直面照度の平均, 最大, 最小值を第 3,4 表に示す.

第 3 表 (和, 室)

\begin{tabular}{|c|c|c|c|c|c|c|c|c|}
\hline \multirow{2}{*}{ 減光遮光 } & \multicolumn{3}{|c|}{$E \quad(\mathrm{~lx})$} & \multirow{2}{*}{$\frac{E f}{E^{-}}$} & \multirow{2}{*}{ 減光遮光 } & \multicolumn{3}{|c|}{$E \quad(\mathrm{~lx})$} \\
\hline & 平 均 & 最 大 & 最 小 & & & 平 均 & 最 大 & 最 小 \\
\hline 1 & 3.02 & 6.29 & 1.37 & 13.6 & 1 & 18.9 & 26.8 & 12.8 \\
\hline II & 3.40 & 6.55 & 1.65 & 12.2 & 2 & 23.2 & 30.7 & 17.4 \\
\hline III & 2.95 & 3.46 & 2.18 & 4.07 & 3 & 18.4 & 28.9 & 9.89 \\
\hline $1 \nabla$ & 1.67 & 2.11 & 1.22 & 5.52 & & & & \\
\hline 平 均 & 2.67 & - & - & 8.85 & 平 均 & 20.2 & - & - \\
\hline
\end{tabular}

第 4 表 (洋穽)

\begin{tabular}{|c|c|c|c|c|c|c|c|c|}
\hline \multirow{2}{*}{ 減光遮光 } & \multicolumn{3}{|c|}{$E^{\prime} \quad(1 x)$} & \multirow{2}{*}{$\frac{E f}{E}$} & \multirow{2}{*}{ 本常通口 } & \multicolumn{3}{|c|}{$E \quad(\mathrm{~lx})$} \\
\hline & 本 均 & 最 大 & 最 小 & & & 平 均 & 最 大 & 最 小 \\
\hline I & 2.54 & 5.55 & 0.73 & 13.7 & 1 & 29.1 & 43.8 & 20.1 \\
\hline II & 3.49 & 4.88 & 2.65 & 3.04 & 2 & 20.3 & 25.5 & 14.3 \\
\hline III & 5.00 & 6.52 & 3.78 & 2.76 & 3 & 25.7 & 33.3 & 18.6 \\
\hline IV & 3.35 & 6.81 & 1.98 & 3.17 & 4 & 29.3 & 38.2 & 21.6 \\
\hline V & 4.46 & 6.38 & 3.27 & 1.46 & 5 & 32.8 & 47.0 & 24.1 \\
\hline 本 均 & 3.77 & - & - & 4.83 & 平 均 & 27.4 & - & - \\
\hline
\end{tabular}

ての表に依ると減光遮光して直射光を無くしを場合の總平均照度は，和室 $2.81 \mathrm{x}$, 洋室 $3.8 \mathrm{~lx}$ で, 洋室は和室より約 $36 \%$ 大きい。之は反射光が和室より多いてとに原因する。

最大照度は總へてをを通じて $7 \mathrm{~lx}$ 超ゆるもの無く，6 lx 以上のものに和室 1，II（金屬製反 射笠）洋室 III（裸電球に遮光板）IV（角照型金屬反射笠）V（床スタンド）等がある. 洋室 I (金屬反射笠) II (外球) 和室 III（裸電球に遮光板）等之に次ぎ和室 $1 V$ は $2.1 \mathrm{~lx}$ で最 暗几。

參考までに和室闌間の照度を测定した所，概して障子面より小さく平均 $1.7 \mathrm{~lx}$ 程であつた。 常識的に明るいてとを豫想される角照型金屬笠の全般照明，白色天井に對する間接照朋等も 
他の方法に依る照度と大同小異であるてとがての結果から知られる：

金盗反射笠の直下に新聞紙 1 枚を敷いた和室 II の方法は，新聞紙の反射に依り漏洩照度を 約13\%增して居ろ.

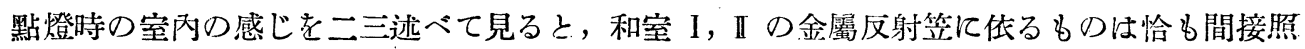
明を逆に行つを場合に相當し，疊面の反射光に依り室內全般が明るくなり思つた程惡いもので b無い.

開放部眞上に角照型反射笠を用ひる全般照明及裸電球に遮光板を併用する方法は, 室內が一 樣に明るく外から見て感じは極敌て皇いが室內に居る者法眩輝を感じる．商店等には外觀の良 い一方法として廣く行注れて居る。

表中 $(E f / E)$ は床又は嚳面の本均照度の, 開放部の本均照度に對する比で, 乙の數值が大 きいてとは同一漏光に對する床面照度の大きいてとを意味する．金屬製反射笠に依る直接照明 はての值が他て擭んでて大きく約 13 で，他は大同小異である。

（ハ）最光となる光束

減光遮光した場合の開放部の平均照度を假定し, 開放部つ面積及一都市の芜數が判ると, 夜 間その都市上空の雲, 霧等に反胦し、て遠距離より認められる光, 即ち最光の光束が求められる.

第 3，4 表よりその本均照度老 $31 \mathrm{x}$, 開放部の平均面棈を一軒當り $25 \mathrm{~m}^{2}$ (凡之戶 15 枚分) と假定すると, 戶數百萬の大都 會の上空に澾する漏洩光束は貫 に $7.5 \times 10^{7} \mathrm{~lm}$ となる・之は $100 \mathrm{~W}$ の裸電球約 58,000 简分 の光束に相當する. この光は勿 論全部が上空に向ふもので江無 く, 一部は土地, 建物其他の建 造物飞當つて反射或は吸收され る.

（=）減光材料の透過率

以上求められた開放部の照度

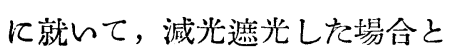
本常通り照明した場合との比を 求めて見ると，第 5,6 表の樣に なる。乙の數字恃平常通り照明 した場合の屋外への漏光を, 減 光遮光した程度に減方る爲め開 放部に設く可き減光材料の透過

第 5 表 (和 缩)

\begin{tabular}{|c|c|c|c|c|}
\hline $\begin{array}{l}\text { 本賞 } \\
\text { 減光 } \\
\text { 廘光 } \\
\end{array}$ & 1 & 2 & 3 & 本 \\
\hline 1 & 0.16 & 0.13 & 0.16 & 0.15 \\
\hline II & 0.18 & 0.15 & 0.18 & 0.17 \\
\hline III & 0.16 & 0.13 & 0.16 & 0.15 \\
\hline IV & 0.088 & 0.072 & 0.091 & 0.084 \\
\hline 平 均 & 0.15 & 0.12 & 0.15 & 0.14 \\
\hline
\end{tabular}

第 6 表 (洋 室)

\begin{tabular}{|c|c|c|c|c|c|c|}
\hline $\begin{array}{c}\text { 平常通 } \\
\text { 減光 }\end{array}$ & 1 & 2 & 3 & 4 & 5 & 平 均 \\
\hline 廘光 & & & & & \\
\hline I & 0.087 & 0.125 & 0.099 & 0.087 & 0.078 & 0.095 \\
II & 0.120 & 0.172 & 0.136 & 0.119 & 0.106 & 0.131 \\
III & 0.172 & 0.246 & 0.195 & 0.171 & 0.152 & 0.187 \\
IV & 0.115 & 0.165 & 0.13 & 0.114 & 0.102 & 0.125 \\
V & 0.153 & 0.22 & 0.174 & 0.152 & 0.136 & 0.617 \\
\hline 平 均 & 0.129 & 0.186 & 0.147 & 0.129 & 0.115 & 0.14 \\
\hline
\end{tabular}




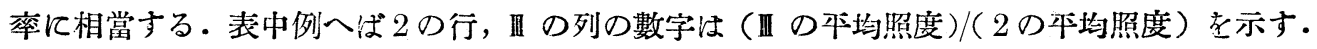

第 5，6 表の總平均は何れも 0.14 で，大體网面印刷した新聞紙 1 枚の透過率に等し、ん.

乙の值は減光程度花 $10 \mathrm{c} /$ 雨 の割合に假定したのであるが， $0.1 \mathrm{c} /$ 坪の場合を考慮すれば， この平均透過率は當然その 1/100 即ち 0.0014 となる。参考

までに透過率 0.14 及 $0.0014 に$ 近へ減光材料の例第 7,8 表 に揭ゲた。

\section{5. 結 論}

以上述べを所を要約すれ代次 の樣になる。

1. 室內の電燈を $10 \mathrm{c} /$ 坪の程度 に減光し且つ直射光が屋外に 向注永に遮光すれば，反射 光を出來る限り大ならしめる 如く照明しても，開放部の鉛 直面照度は 7lx 老超えず, 平 均值は $3 \mathrm{~lx}$ 程度である。

2. 乙の程度に減光しても照明 方法宜しきを得れば 50 100lx 程度の作業面照度 を得る事はたやすん。ての照 度は普通の作業には先づ支障 の無い值である。

第 7 表

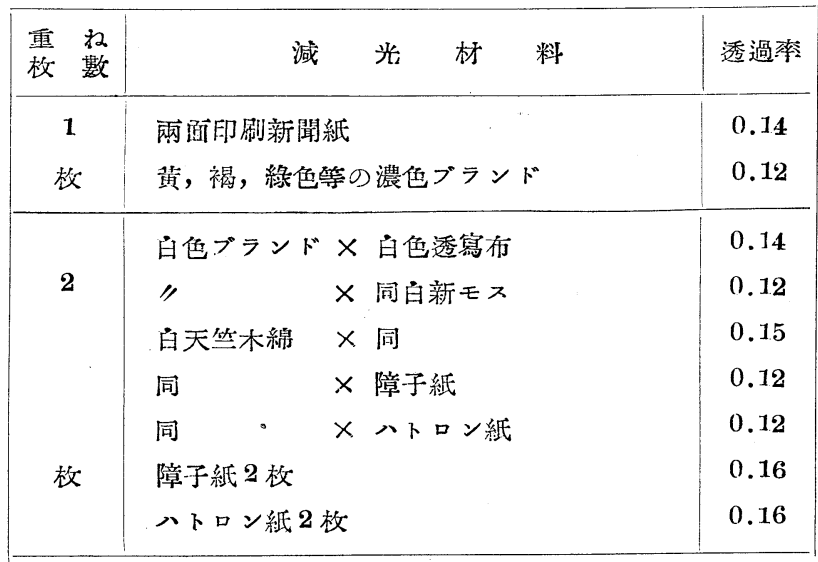

第 8 表

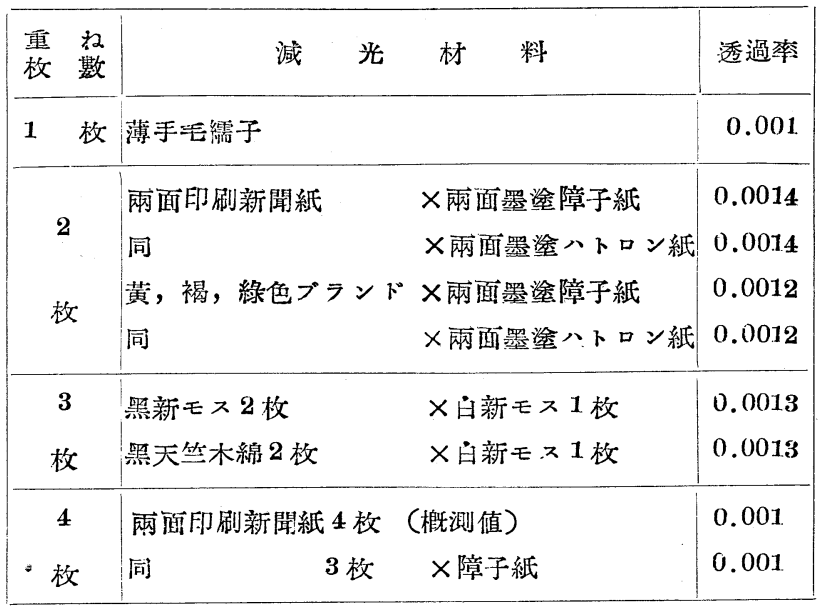

3. 同一漏洩光束几對して, 作業面の平均照度を最も大きく䳕し得る照明方法は, 效率の良い 金屬反射笠に依る直接照明であつて，平均開放部の照度の約15倍である。

4. 洋室よりの漏光は室內周圍の反射率が高い爲め，和室より約 $40 \%$ 程大きい。

5. 室內の照明を本常通り維持しても，開放部に透過率が新聞紙 1 枚程度以下の減光材料を施 せば，屋外への漏光は前項 1 .の減光遮光を行つた程度に減ずる。

(附 記)

燈火管制上の用語の使用及び燈火管制規定等に觸れること老避けた爲め, 稍意味の明膫を缺 く點があるが御諒承願ひたい。 